\title{
Satoyama Landscapes and Their Change in A River Basin context: Lessons for Sustainability
}

\author{
Shamik Chakraborty (Corresponding author) \\ Institute for the Advanced Study of Sustainability (IAS), United Nations University \\ 5-53-70 Jingumae, Shibuya-ku, Tokyo, 150-8925, Japan \\ Tel: 81-3-5467-1212Ｅ-mail: chakraborty@unu.edu
}

Abhik Chakraborty

Center for Tourism Research, Wakayama University

930 Sakaedani, Wakayama city, Wakayama, 649-8441, Japan

Tel: 81-73-456-7025Ｅmail: abhichkro@gmail.com

\author{
Received: March 10, 2017 Accepted: April 6, 2017 Published: June 14, 2017 \\ doi:10.5296/iss.v5i1.10892ＵRL: http://dx.doi.org/10.5296/iss.v5i1.10892
}

\begin{abstract}
'Satoyama' denotes a mosaic of different landscape-types that has sustained agrarian societies for millennia in Japan. These landscapes have undergone degradation during the past few decades. While satoyama is a consistently referred term in landscape management in Japan, little attention is given to how such landscapes undergo change in large spatial units such as river basins. This study, based on documents and interviews, reviews how watershed level changes affect the functioning of such socioecological systems in the Kuma River Basin in Kyushu. Watershed properties of the Kuma River Basin changed during pre-modern and modern times and each phase left a lasting legacy on the landscape. The article analyzes how ecological connectivity became fragmented by identifying changes in ecosystem services, and concludes that while socio-ecological landscapes have a long history of human use; the human component cannot outgrow the fundamental biophysical processes that maintain ecosystem services and system resilience; these systems can undergo swift and irreversible degradation when ecological connectivity is fragmented. The main lesson for sustainable development is that consideration of historical changes in land use is vital for understanding the connectivity of different components in satoyama landscapes; this insight is important not only for rivers but also for the wider landscapes they connect and the associated integrity.
\end{abstract}


Keywords: land use history, socioecological landscapes, satoyama, river basin, Japan 


\section{Introduction: Socio-Ecological Landscapes and Satoyama}

Over the recent years, coupled socio-ecological systems have come to be seen as of vital importance for nature conservation and sustainable development (Berkes, 2004). Otero et al. (2013) point out that "...the science of ecology and the various fields of applied ecology have experienced a conceptual shift toward the understanding of ecosystems in which humans are an integral part" (25). The study of socio-ecological landscapes is especially important because they have sustained local societies for millennia; while at the same time they are becoming increasingly degraded due to human interference (Takeuchi et al. 2003, Fukamachi et al. 2001, Cetinkaya, 2009). In Japan, the term 'satoyama' is used to denote a type of socioecological landscape that is noted for 'mosaic' of different types of forests, shrubs or grasslands, rice paddies and other agricultural landscapes (such as vegetable gardens and fruit orchards), low elevation hills, rivers, wetlands and ponds (Fukamachi et al. 2001; Yokohari et al 2001). Although this kind of landscape is not particular to Japan, it can be found all over Asia where sedentary communities have shaped landscapes over millennia (Indrawan et al. 2014); its most obvious association is with the socioecological landscapes in the Japanese archipelago (Duraiappah et al. 2012). Sedentary rice farming communities are an essential part of this system; satoyama in Japan has nourished such communities for over 3000 years and formed a rich ecological knowledge base in the process (Katoh et al. 2009; Kobori and Primack, 2003). Satoyama is also a buffer landscape comprising of forests, woodlands and grasslands and it typically lies between wilder mountain forests and agrarian villages. Satoyama therefore is an 'inclusive' term; one that has landscape diversity as its core notion. It also has a considerable spatial variation, which is mainly due to different biogeographical characteristics of the archipelago that in turn affect vegetation (Inui, 2002; Chakraborty and Chakraborty, 2013). Though term satoyama literally means 'village mountain', Inui (2002) notes that a typical satoyama landscape does not usually have high mountains. The word 'yama' (mountain) is actually used to denote forests. Because $70 \%$ of the land area of Japan is mountainous and forested, these two landscapes were seen as intertwined in premodern Japan. All these characteristics also make it difficult to provide a succinct definition of 'satoyama'; it is in essence a patchwork of semi-wild forested, agrarian and even coastal landscapes. This 'patchwork' or 'mosaic' characteristic provides a range of ecosystem services. The Japan Satoyama Satoumi Assessment (Duraiappah et al. 2012) mentions that satoyama has been 'managed to produce bundles of ecosystem services for human well being' (Duraiappah et al. 2012: 4, see also Yokohari \& Bolthouse, 2011). During Japan's postwar economic development, these socio-ecological landscapes gradually became dissociated from communities, resulting in their eventual decline (Kohsaka et al. 2013). This has led to calls for rejuvenating and conserving them. Conserving socio-ecological production landscapes such as the satoyama is imperative because in general, landscape diversity continues to decline at the global level leading to degradation of habitat connectivity and biodiversity loss (Lindborg \& Eriksson, 2004; Honnay et al. 2005). Furthermore, in Japan these landscapes offer the last refuge for many endangered plant and animal species (MoE, 2001 in Watanabe et al. 2012). 


\section{Mll Macrothink}

However, the majority of the satoyama conservation discourses focus on particular resources from the landscape and ignore the larger reality of landscape degradation over wider scales. Many prominent satoyama scholars have spoken for 'restoration' of this socio-ecological landscape through 'better management' and implied that a general lack of resource use from this landscape have contributed to its decline (Sano et al. 2006; Katoh et al. 2009). As socio-ecological landscapes are spread over multiple spatial and temporal scales, change and degradation occur on those different scales. A notable approach is to see the pathways of change in larger units such as 'watersheds'. In their seminal paper, Ward and Stanford (1995) explore the concept of 'ecological connectivity', noting how terrestrial and aquatic ecosystems are interrelated, how natural disturbance regimes create landscape mosaics that are integral to the ecological connectivity of river systems and how flow regulation schemes can impact such dynamic systems. Wohl (2005) has noted that for river restoration it is necessary to understand the 'compromised' river functions, which degrade its natural disturbance regimes. Bahar et al. (2008) notes the importance of forest ecosystems for rivers that flow through human dominated systems of cities and villages; and Nagayama et al. (2009) argue for natural landscape process as a restoration pathway for bringing back natural riverscapes. Haslam (2008) notes the importance of river landscapes or 'riverscapes' for the restoration and conservation of riverine ecosystems, a notion still largely under used in river basin conservation efforts. Such landscape based approaches to river conservation is especially vital for Japanese rivers which have a high rate of endemic species (Yoshimura et al. 2005), and where the quality of water has improved even as overall basin ecology has degraded (ibid).

In the Japanese context especially, river basins have been a major casualty of the postwar economic development, and instructive lessons for conservation of socio-ecological landscapes can be derived from the changes at the watershed level. While rivers such as the Shimanto and Nagara-known for their beautiful vistas and sport-fishing resources - have been analyzed to some extent (Kubota, 2008, Ono, 2010), river basin level change and its connection to the socio-ecological satoyama has not been analyzed adequately. This article, by focusing on a particular river basin, brings out the contours of change that affect socio-ecological landscapes. This has obvious implications for sustainable development for highly industrialized societies through appropriate utilization of remaining natural spaces.

\section{Methodology}

This paper is based on 3 months of field and desk research carried out in the Kuma River Basin, in Kyushu, Japan. The first author visited the villages of Itsuki, Mizukami, and Kuma, the town of Asagiri, and the cities of Yatsushiro and Hitoyoshi in the Kumamoto Prefecture. A qualitative framework was used for the study with in-depth interviews, and direct observations. Data from secondary sources were used to map the cultural histories of the river basin associated with land use. The qualitative design allowed researchers to compare data over a long time scale, and across multiple levels (Creswell, 2002). The interviewees constituted local fishermen, farmers, local businessmen, owner of local restaurants and local environmental activists. The interviewees were chosen through a key informant in the field who has long-term experience about the changes in Kuma river basin. The chosen age of the 


\section{Macrothink}

Issues in Social Science

ISSN 2329-521X

2016, Vol. 5, No. 1

interviewees was over 50 so that they could reflect their (experience-based) opinions about past landscapes.

The paper uses the ecosystem service (ES) framework to understand connections between landscape (riverscape) level processes. The ES framework has been adopted from the Millennium Ecosystem Assessment (MEA, 2005), with four broad categories: provisioning, regulating, cultural and supporting services. The ES framework is recognized as a key means to study the state of the ecological systems (Fisher et al. 2009, Gomez-Baggethum et al. 2010). Consequently, a 'before and after (large scale basin engineering)' scenario is discussed, sketched out of data gathered from literature and interviews.

\section{The Study Area}

\subsection{The Kuma River Basin}

The Kuma River (length $116 \mathrm{~km}$, basin area $1882 \mathrm{~km}^{2}$ ) forms a major watershed in central Kyushu Island in Southwest Japan. It originates from Mt. Choushigasa (1489 m.asl) and flows mainly through the Kumamoto (figure 1). At Hitoyoshi City it is joined by the Kawabe River (length $62 \mathrm{~km}$, basin area $533 \mathrm{~km}^{2}$ ), which originates from Mt. Kunimi (1739m). The Kuma has about 80 tributaries with a combined length of $434 \mathrm{~km}$. (Ibid). The basin has a circular shape, which indicates a good water and sediment transport function. The river flows through a steep gradient in its upper course (from source to the Ichifusa dam), abruptly changing to a moderate gradient at Hitoyoshi basin, (from below the Ichifusa to its confluence with tributary Bahyo), and through a narrow valley downstream (from below its confluence with tributary Bahyo to the foothills of Hacchozan). Then it branches off into numerous channels before merging into the Yatsushiro Bay. The rainfall pattern in the watershed has a strong monsoonal influence. Rainfall amount varies between $70 \mathrm{~mm}$ to more than $470 \mathrm{~mm}$; most of the rainfall occurs during June and July and gives rise to short but violent flooding at times. Relatively flat to gently sloping areas such as the Hitoyoshi Basin are prone to flooding incidents more due to sudden decrease of the channel slope.

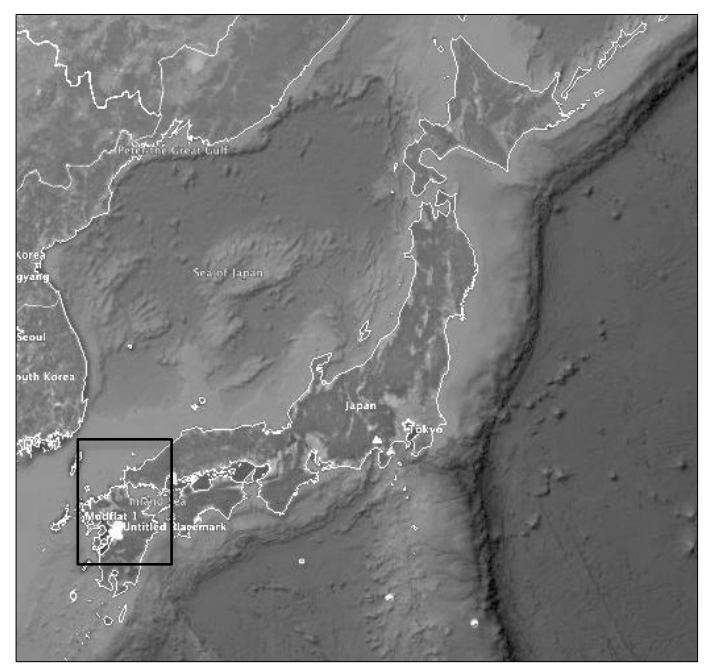




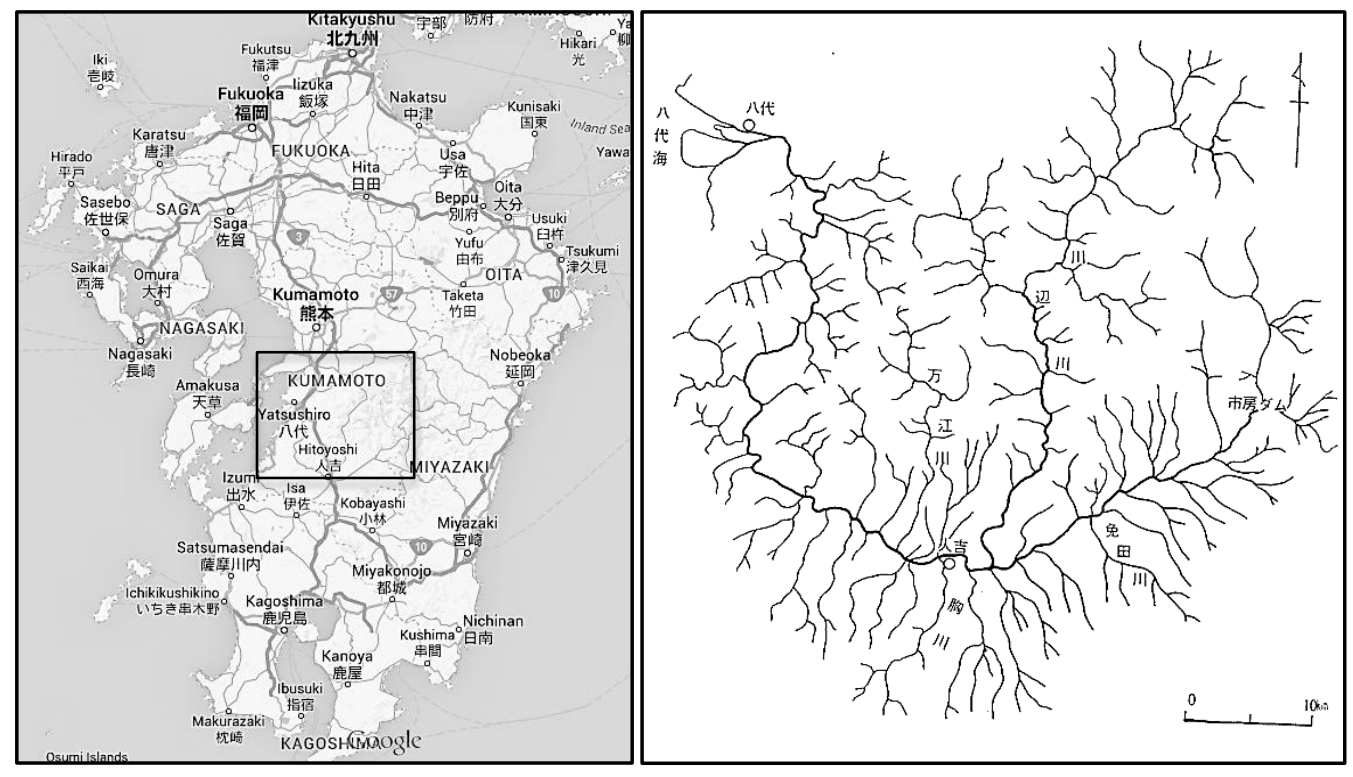

Figure 1. Location of the Kuma River basin (Source: Google Map, Ushijima 1984)

The hydrologic characteristic of the basin is dominated by a very steep gradient (a common characteristic of nearly all Japanese rivers) with a ' $\mathrm{V}$ ' shaped valley. The riverbed is rich in boulders and cobbles, although there has been a significant change in the bed form due to human influence in the recent years. Compared with the heavily engineered rivers of Japan that resemble concretized channels, the Kuma retains a comparatively high degree of natural landscapes. The river still has a prominent pool and riffle sequence, but local fishermen and environmental activists indicated that conditions have deteriorated over the years.

Forests in the Kuma river basin have been affected by heavy human influence. The climax vegetation can be divided into two broad categories: cold temperate type represented by Japanese Beech (Fagus crenata), and warm temperate type represented by varieties of evergreen oak. Beech forests hold a lot of water in the tree trunk and root system: while this is vital to the water retention property of the watershed, this made the Beech unsuited for fuelwood. During the postwar development period large tracts of Beech forests were felled all over Japan and this watershed was no exception. The socio-ecological connections in the landscapes are characterized by interlinkage between forests, agricultural fields, rivers and the estuarine system. The river itself is a good example of ecosystem connectivity as indicated by the springtime migration of Ayu or sweetfish (Plecoglossus altivelis) upriver from Yatsushiro Bay for spawning. A unique estuarine ecosystem has formed due to the coupled action of the river and the shallow, relatively closed Yatsushiro Bay. The system attracts at least 43 different types of fish to the river (Note 1) (MLIT, 2013) together with a number of mollusks and crustaceans that are endangered, threatened or vulnerable (MLIT, 2006). Seabirds such as ducks, gulls, plovers, and curlews also inhabit the area: the mudflat of Kuma River is recognized as one of the important bird areas of Japan (Wild Bird Society of Japan, n. d.). 


\section{Macrothink}

\subsection{The Socio-political Background}

The Kuma River is a vital source of food, drinking water, economy, and recreation for its basin society. However, once renowned for its fish diversity and abundant water resources, the river and its associated bay ecosystem suffered degradation of the natural environment in the last 50 years mainly due to constructions of dams, barrages, and concretization of waterways. Consequently ecosystem productivity has declined and its effects are felt in the basin society. The traditional human-environment interactions have changed, reflecting the changes in the satoyama landscape in the basin. Of late, the watershed has attracted attention for the stoppage of a large dam project through citizen protests and a successful case of dam decommissioning. The Kawabe River became known for a vigorous anti-dam movement led by local citizens that became one of the most prominent examples of successful stoppage of a large dam construction in Japan. Currently, the Arase Dam in a tributary basin is planned for removal, marking the first dam removal activity in Japan (Tanabe, 2014). The dam is expected to be removed completely in the year 2017.

\section{Transitions in the Land Management Regimes: A Historical Narrative}

\subsection{Pre-Edo to Meiji Periods}

Shiiba and Utsumi (2010) in their study of the Shiiba village in Miyazaki note how during the Edo period (1603-1868) the Hitoyoshi fief started controlled felling of forests in the mountain slopes, and how the age-old swidden system was affected negatively. But during the subsequent Meiji period, the fief laws became nonexistent and swidden systems started again (Ibid). During this time, slash and burn agriculture was a major means for resource utilization in the basin (Yamamoto, 1957). Slash and burn cultivation was important for sustenance of the forested villages before coppicing culture became prevalent. This practice was used to produce crops such as barley (Hordeum vulgare), Japanese millet (Echinochloa esculenta), azuki beans (Vigna angularis), sweet potato (Ipomoea batatas), chestnut (Castanea), corn (Zea mays), dry rice, and taro (Colocasia esculenta). This type of agriculture remained small scale and declined steadily during the modern periods. The surrounding mountains were characterized by evergreen broadleaf forests (Note 2) mainly characterized by varieties of oak with Beech (Fagus crenata) in the higher elevations from 700 -1,600 meters (Miyawaki, 1984). 


\section{$\Lambda$ Macrothink}

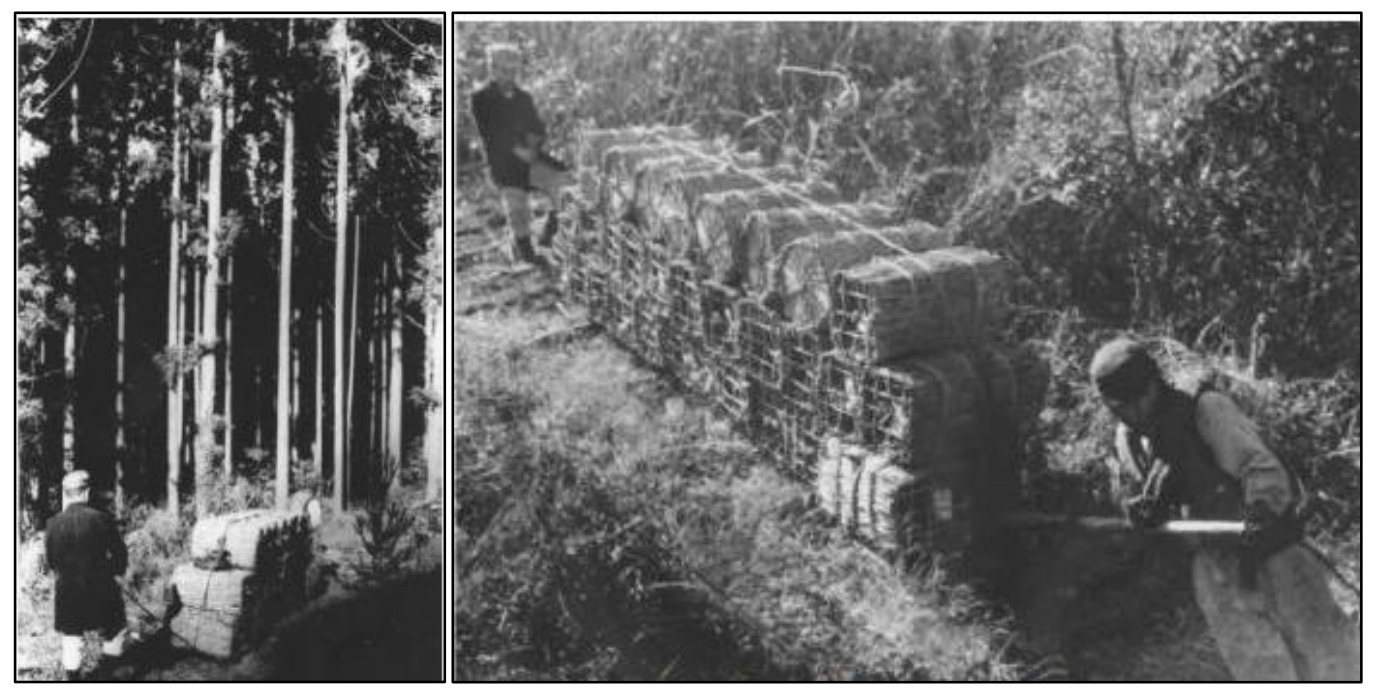

Figure 2. Carrying of charcoal from forest. (Source: Mugishima, 1949 a)

In the lower elevation areas, wet rice cultivation was the most dominant driver of landscape transition until the large-scale urbanization of the late $20^{\text {th }}$ century. Maintenance of landscapes through wet rice cultivation required more dependence on the river. Interventions were made in the flow regime first by making flow diversions, and then by making dams. Below we give a short description of these flow interventions. The early changes to the river's hydrology were followed up by engineering projects of the powerful feudal lord Kato Kyomasa (1562-1611) who ruled in Azuchi Momoyama (Note 3) and Edo (Note 4) periods. Kyomasa's policies were instrumental in changing the lower courses of the four major rivers of Kumamoto: Kikuchi, Shira, Midori, and Kuma through making levees, dikes, and barrages (Tanaka et al. 2005). The original channel in the river mouth had an anastomosing form, and was divided into three main channels. The channel form was changed for land reclamation and channelization, mainly for rice cultivation and flood control. Kyomasa erected a barrier to the flow of the river in 1330 in the same area where the present day Yohai barrage is located (Ibid), and stones were used to strengthen the riverbanks. However, unlike the dams and the Yohai barrage that were constructed during the $20^{\text {th }}$ century, these changes did not cause a complete break in the long profile of the river.

From the second half of the $17^{\text {th }}$ century economic and social drivers led to further change in the basin landscape. In his book Kumagawa Monogatari (A Tale of Kuma River), Mitsunori Maeyama (1997) notes that around 1662, a local businessman Mahashi Masamori started transport business by using the river as a 'highway'. Boulders large and small were taken out of the river to make way for the boats. This was significant river engineering at that time, which affected a large part of the Kuma River all the way from Yatsushiro to Hitoyoshi. This shows that the river had already undergone significant changes in the before the modern times, which had significant repercussions on the hydrological characteristics and ecosystem properties of the watershed. Unfortunately very little data is available on such changes. Once opened, the 'river highway' increased commercial interest in the Kuma River: the key players who took advantage of this change were the local feudal lord or daimyo and his retainers 


\section{Macrothink}

(Note 5). These officials needed to go to Edo (Tokyo) every other year to pay tribute to the Shogun; this system was known as sankinkoutai.

Table 1. Historical land use types and their characteristics of the Kuma river basin. Information below the black line in the table is also explained in the ecosystem service benefits described in Figure 7

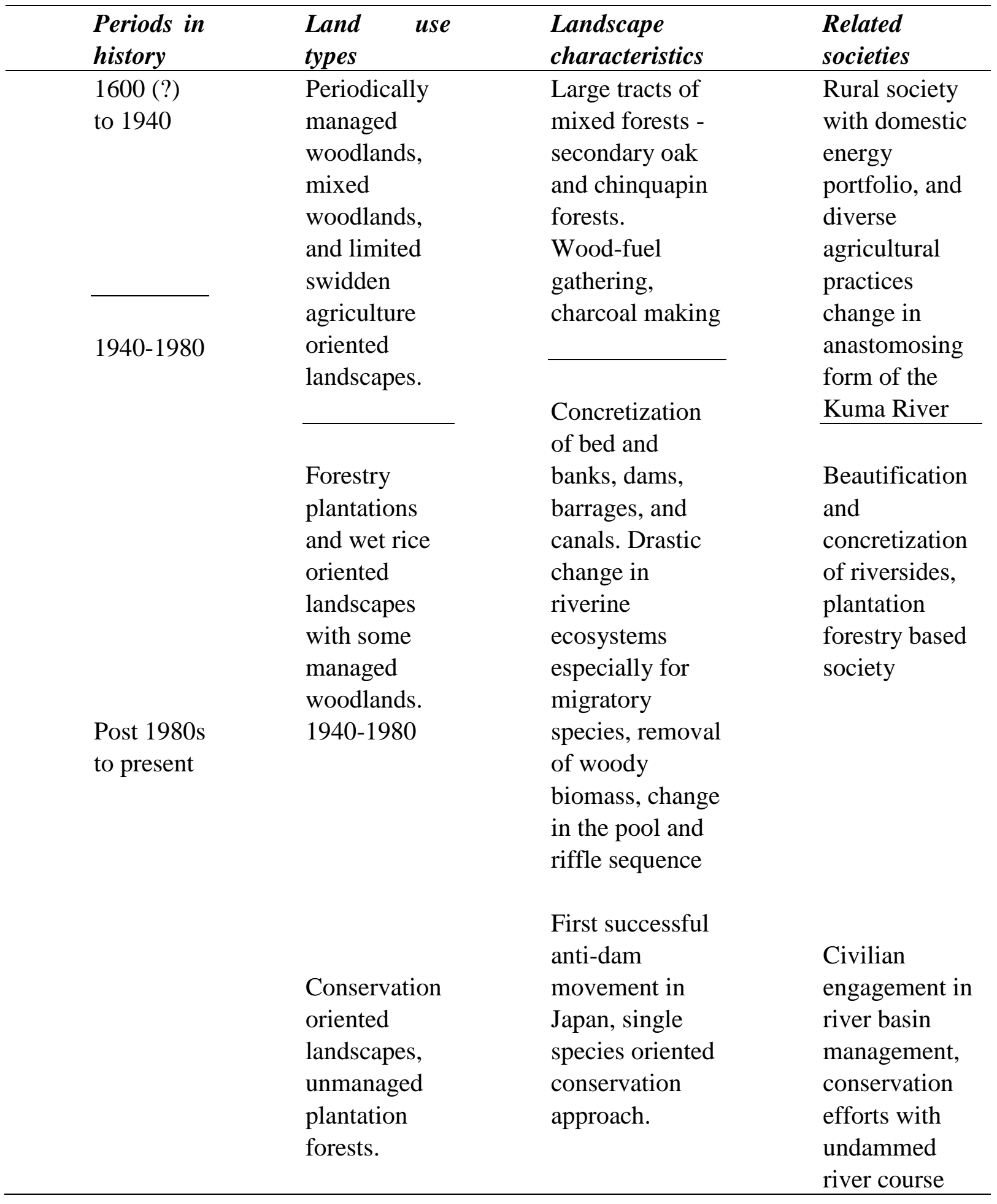

Source: Literature review and interview data 
A prominent change was the alteration of the alluvial fans in the middle part of the river's course. By the start of the $18^{\text {th }}$ century, two drainage canals, Hyakutaro and Kouno, were completed to bring water to lands not suited to agriculture (MLIT, 2006). This marked the start of large-scale land development for agriculture in the alluvial fan that eventually resulted in large-scale flow diversion of the Kuma River (figure 4 b). However the challenge to harness the river basin did not end there because the soil around the Hitoyoshi basin is highly porous and does not have a good water retention capacity due to the presence of volcanic ejecta from Kirishima Mountains. Such landscape properties are not conducive for wet rice cultivation and they provided a major impetus for later large-scale concretization in the $20^{\text {th }}$ century.

\section{$4.220^{\text {th }}$ Century}

The above-mentioned agricultural practices continued till the beginning of the twentieth century. Gradually, improvements of agricultural technology with intensive wet rice cultivation caused abandonment of slash and burn fields. Abandoned lands were planted with coppice woodlands with periodic management interventions (cutting and pruning). Takeuchi et al. (2003), JSSA (2010) and Brown and Yokohari (2003) explain in detail how Japanese forests were managed through controlled periodic disturbances such as wood-fuel and charcoal gathering; this necessitated systematic cutting and pruning in every 10-15 years (Takeuchi, 2003). In Kyushu, these managed forests included varieties of evergreen oak (Fagaceae) and chinquapin (Castanopsis) woodlands. Mountain forests during these times $\left(17^{\text {th }}\right.$ Century to early $20^{\text {th }}$ Century, see Table 1$)$ were characterized by intervening stands of Japanese cedar (Chamaecyparis obtusa), Japanese cypress (Cryptomeria japonica), evergreen oaks, and chinquapins, together with agricultural plots in-between producing varieties of millets, buckwheats and beans. Charcoal, used for cooking and heating, was taken through narrow timber roads with wooden tracks (known as 'kinma-michi' or 'kinba-michi') (Kumamoto Nichinichi Shimbun, n. d.). These roads, 5 to 6 feet in width (figure 2), were used for taking woods from the forest to the river; and they were used for opening up forest tracts in the upper parts of the watershed.

From the 1940s Japanese cedar plantations (Cryptomeria japonica) increased rapidly in the river basin. During this time the old method of slash and burn agriculture existed only in patches and the practice gradually declined after the Second World War (Shiiba and Utsumi 2010). During the post war economic growth period this cultivation technique gave way to large-scale plantation forestry (ringyo). A major reason for the decline of forests in the Kuma River Basin was extraction of roundwoods for Yatsushiro's paper industry (Save the River Kawabegawa, 2007) (Note 6). Instead of coppice woodlands the conifer plantations started to increase from this time (figure 3). The Kuma River's swift flow was used to transport logs from these planted forests on rafts locally called ikada (Mugishima, 1949 b). Interviews with the locals suggested that during the peak time about 30 to 40 such rafts were seen in the river in a single day. 

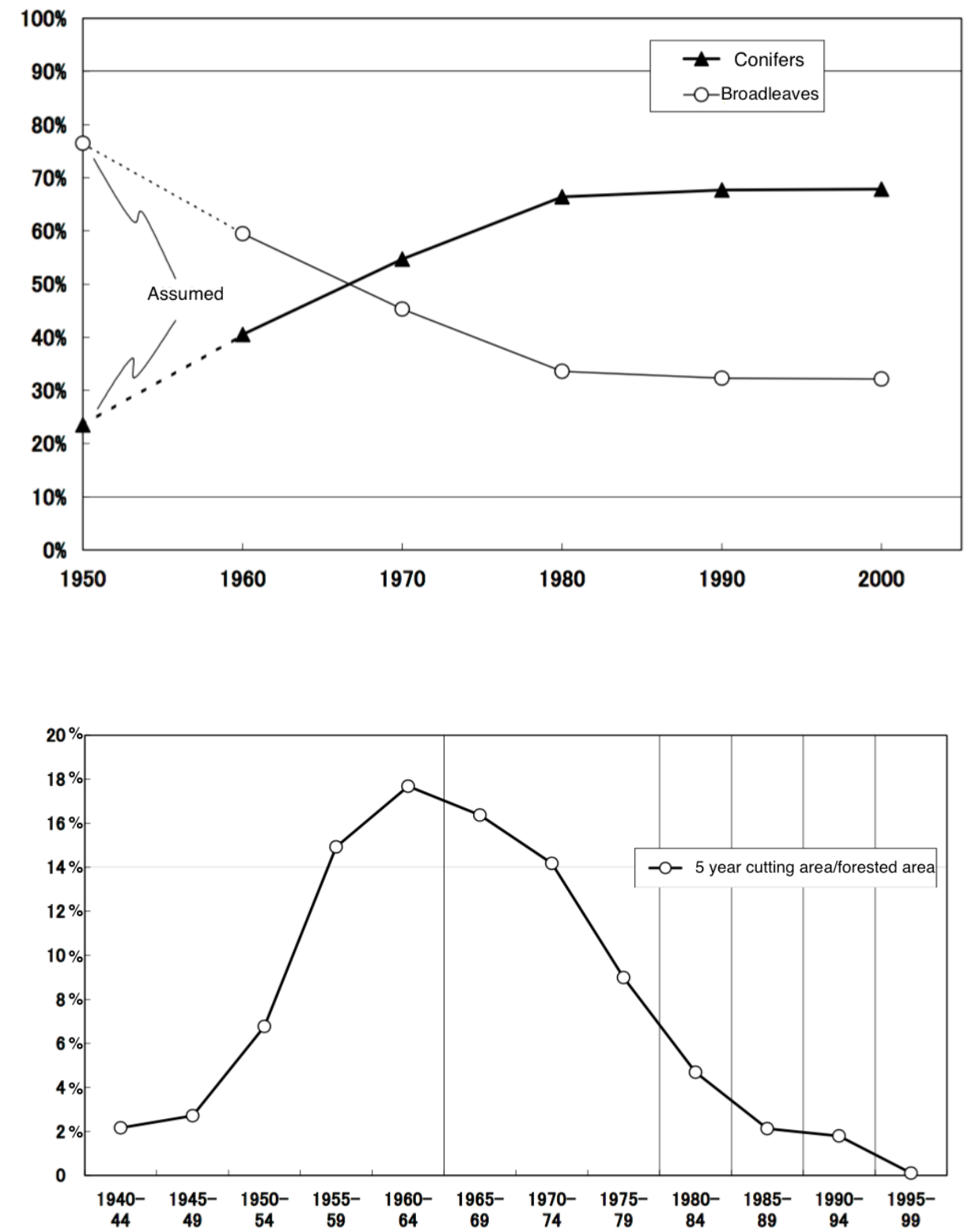

Figure 3. Amount of deforestation due to plantations of conifers in the Kuma River Basin. Source: Save the River Kawabegawa, 2007. (English captions by the authors) 

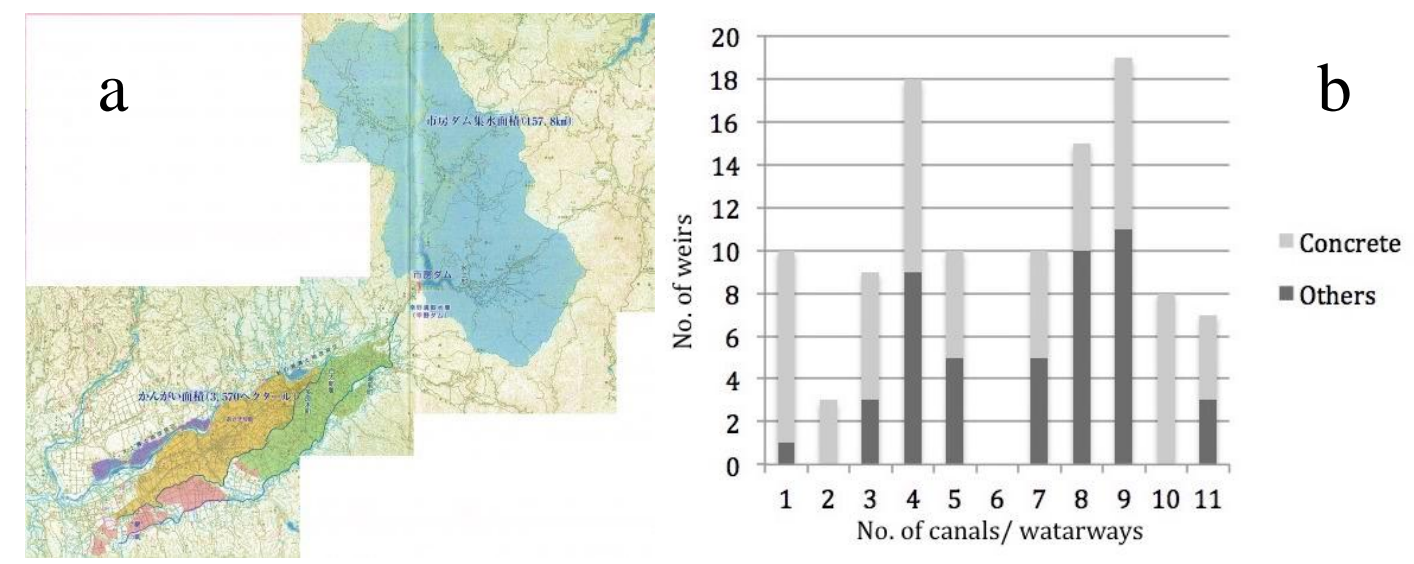

Figure 4. a: Alluvial fan areas drained by canals from Ichifusa dam (yellow and green shades).

The catchment of Ichifusa dam is shown in light blue. (Source: Kumamoto Prefecture

Website). b: Number of weirs in the 11 tributaries of the Kuma River at Hitoyoshi

Source: Yamauchi, 1980

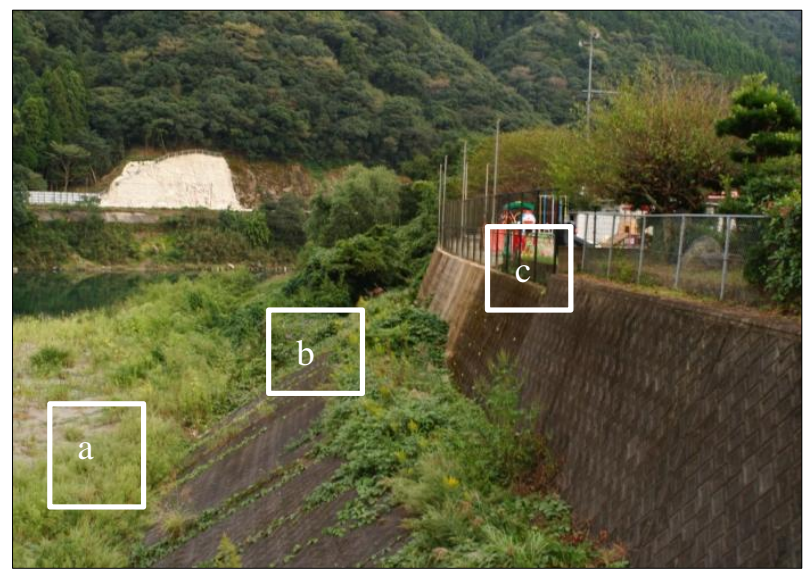

Figure 5. a. Channel bed, b. Height of the surrounding lands before dam c. increase in the height of the land called 'kasa-age' after dam construction (Photograph by the authors)

In the post war period, large dams and barrages-Ichifusa, Setoishi, Arase, Yohai, and Kumagawa - came to dominate basin landscape features. The Ichifusa Dam has the most pronounced effect on the fan areas of Hitoyoshi basin (figure 4 a). The dams of the Kuma River Basin were built primarily to flood-proof the watershed in order to facilitate large infrastructure development and to meet energy needs. The Kuma River comprehensive development plan was formulated in 1951 to harness hydropower by erecting 7 dams and 10 power plants (Japan for Sustainability, 2014). However the dams could not stop flooding completely, in some cases they arguably worsened the flood situation (Kumagawa Ryuiki Jumin Kikitori Chosa Hokoku Henshu Iinkai, 2008, Takahashi 2009). In 1965 the Ichifusa Dam released a large volume of water as the dam was threatened with a major inflow from 


\section{Macrothink Institute ${ }^{T M}$}

upstream, and this release flooded areas downstream, causing an 'artificial flood' (Takahashi, 2009). In the late $20^{\text {th }}$ century, citizen protests managed to halt a large dam construction in the Kawabe River, and similar sentiments resulted in the scrapping plan for the aging Arase Dam (figure 6). These incidents became known as major success stories of citizen-led river basin management in Japan (Committee for Dam Removal 2010). While the stoppage of the Kawabe river dam is generally seen as a success story for environmental concerns it is to be noted that stoppage of a dam does not always reduce harmful effects on the landscapes. Even before a dam is erected its planning phase leaves a considerable influence on the riverine environment. In the Kawabe River case, villages were resettled above the planned dam height, known as kasa-age (figure 5). The associated materials (complex of rocks and soil) needed for the construction were brought from the nearby mountains-leaving them denuded. Such effects still remain in the landscape.

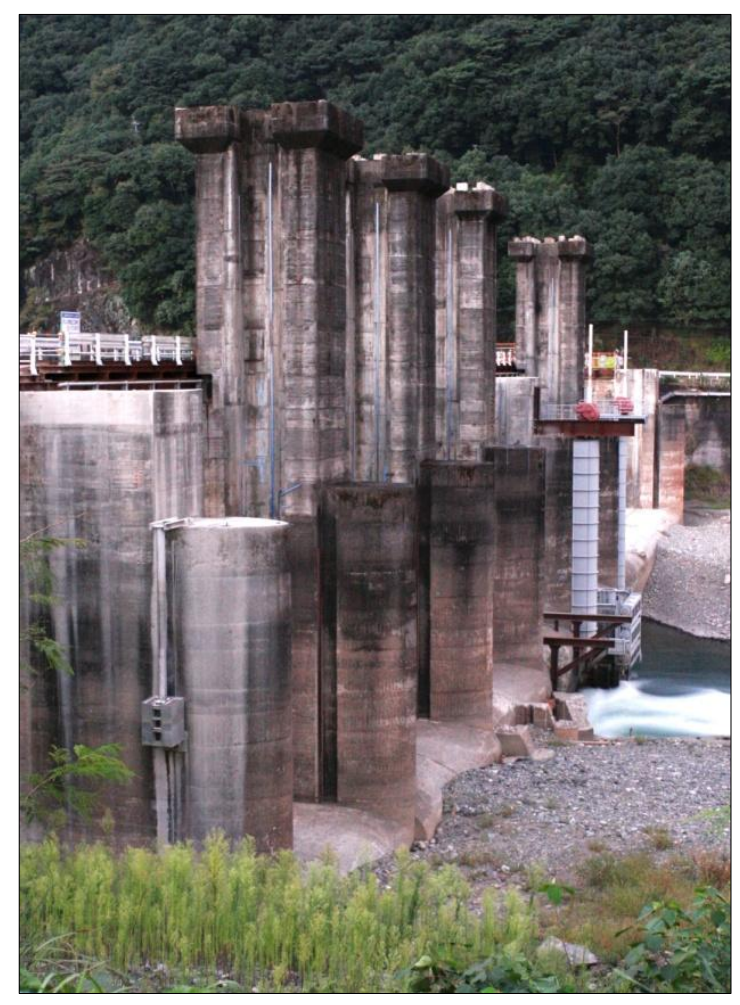

Figure 6. Arase dam before its removal (photograph by the authors)

\section{The Ecological (and Socio-Ecological) Implications of Anthropogenic Change at the Watershed Level}

In this section we describe the results of the interviews with locals about different ecosystem services from the landscape and focus on importance of basin landscape and provide our own opinions based on our observations and experiences with river basins in Japan. 


\subsection{Change and Erosion of Ecosystem Services (ES) in the Watershed Landscapes}

Social-ecological components-slash and burn agriculture, coppicing, management of rice paddies, upland forests, grasslands, and wetlands - maintained the ecological and social well-being of the Kuma River Basin through maintaining a diverse landscape. Past land use practices based on direct dependence on natural resources could be related to higher self-sufficiency; denoting a coupled human-environmental systems that had an important role to play in the maintenance of ecosystem service bundles (figure 7). Diverse agricultural land uses can address both issues of biodiversity and human health as biodiversity depends on how humans produce food (Wilby et al. 2009), and also supports diverse sources of food for a healthy diet (Hillel \& Rosenzweig, 2008). The interviews conducted in the river basin, with literature analysis show how ES have become simplified and 'eroded' in the aftermath of large-scale human alteration of the basin ecology. Landscape patches with boradleaf forests, unregulated river flows, together with slash and burn fields, coppice woodlands, and wetland rice provided a number of different provisioning services until later half of $20^{\text {th }}$ century. The effects of wilder forested areas and unregulated (natural) river regimes are key components of a diverse and resilient landscape mosaic. Agro-ecological landscapes, especially those that connect wild areas (forests, unregulated rivers) to small scale sedentary settlements can benefit from resource flows (ES) across the whole landscape but when major structural barriers such as dams obstruct flow pathways such ES flow maintenance becomes increasingly untenable. This is because most of the nutrient flows in agricultural landscapes comes from the landscapes outside the agricultural areas and includes biomass, organisms and their genes and abiotic earth elements (Swift et al. 2004). As for example, without nutrients from the forest biomass, slash and burn agriculture is not possible; this shows the relationship between the two landscape patches through regulating and supporting ecosystem services. But land uses such as wet rice cultivation can cut off principle connection pathways. Furthermore, about the energy utilization from the landscape (a principle feature of satoyama) Brown and Yokohari (2003) note (Note 7) that wood-fuel gathering does harm primary forests, but where periodic use (coppicing) takes place, pressure from gathering wood-fuels from forests and forest margins are reduced, because coppicing takes place in an 8 to 20 year cycle where it is possible for the same parcel of land to be used for years. Hence, they argue, coppicing cultures are indirectly connected to regulating and supporting services. Since coppicing allows sunshine to penetrate the forest floor, in-spite of being a human managed system, it allows for the natural cycle of regeneration and decay and a number of animals depend on this cycle such as insects, birds, squirrels, martens, rabbits, wild boars and deer when compared to industrial (mono-cultural) plantations of Japanese cedar and cypress. Such woodlands also provided cultural benefits through recreation opportunities such as playing and picnics with family and friends, and watching birds and insects. 

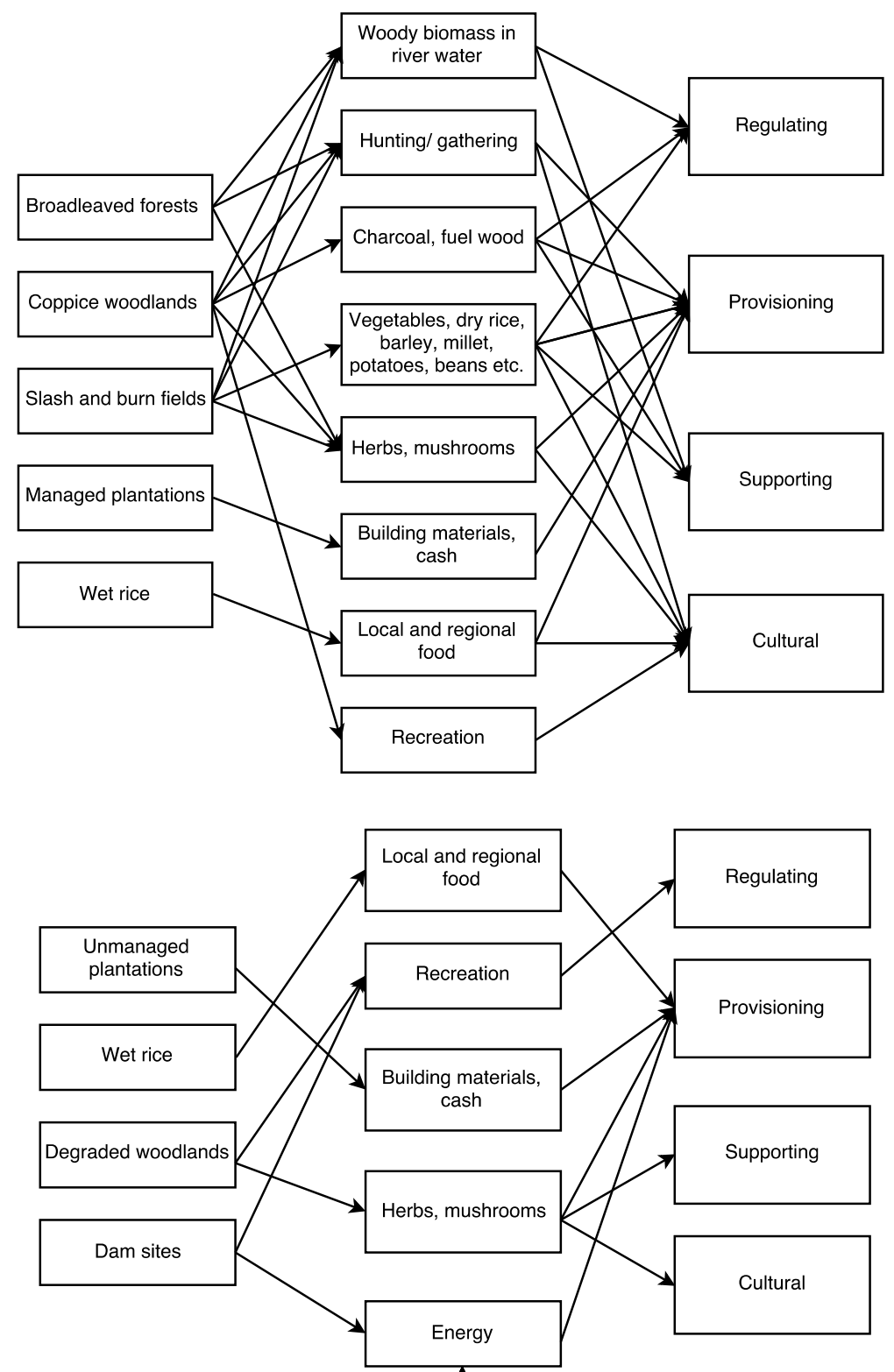

Figure 7. Principal landscape components and their changes in the Kuma River Basin before and after the post-war basin developments (results from interviews and literature review)

Provisioning of ecosystem services is generally under pressure from global change (Seidl et al. 2015). The change in a specific (local) socio-ecological landscape is more than just a change of its particular functions; it reflects a more pervasive, spatially heterogeneous change over the larger units of the landscape (in this case; the Kuma River watershed). Without considering this qualitative landscape history, heterogeneous changes that affect a large region such as a watershed over longer units of time are difficult to understand. Ward (1997) points out that rivers must be seen in their landscape context. As this case study indicates, this is highly relevant for sustainable management of socio-ecological production landscapes such as the satoyama of Japan. While the general notion of these landscapes is that of a 'human-centric' (managed) system, if we take a larger spatial and temporal unit such as a 
watershed to see how ES from socio-ecological landscapes are connected to the biophysical (natural) processes of the river and forest systems, we are able to appreciate this important angle. Understanding of such connections should help recover lost ecosystem functions and socioecological resilience of satoyama landscapes in the future.

\subsection{Ecological Repercussions with loss of ecosystem benefits along the riverscape}

In terms of their effect on the satoyama landscapes that connect mountains, rivers, forests and seas, changes can be categorized into two main levels. First, from pre-Edo to Meiji periods the cross profile of the river was affected by land use. Next, in the $20^{\text {th }}$ century and post WWII period dams broke down the flow of resources crucial for ecosystem health and the long profile of the river was affected. The Kuma River case offers an example of these two different levels of interventions in the river regime and their connection to the changes in surrounding (wider) landscapes. Basin physiography allowed limited agriculture options in the upstream part until canal systems like Hyakutaro and Kouno were completed. Also in the early modern Edo Period (1603-1868) forests in the watershed were felled over large areas. The disappearance of such forest varieties is an important marker in the change of the socioecological landscapes.

From the agricultural land-use point of view, two distinctive landscapes types could be identified: the slash and burn agriculture (low water intensive) and wet rice agriculture (high water intensive). Slash and burn agriculture diminished by the post war period, and the landscape was converted into dense conifer plantations (reduced species diversity), which resulted in a loss of ecological productivity of the land. Wet rice cultivation required extensive engineering of the waterways. Thus, the history of man-made change on water landscapes has its continuity from flow diversion to dams. Increased commercial use of the river led to alteration of channel properties from the $17^{\text {th }}$ century. Nevertheless, large dams and barrages of the $20^{\text {th }}$ century in the watershed form the biggest rupture with the past. This is because dams cut off vital ecosystem mechanisms across the larger spatial scales of the landscape. This did not only change the resource use but also changed the way in which people perceived the river. An example can be given of flooding events, which were not necessarily seen as a 'hazard' by pre-modern societies (Note 8), periodic overflowing of the river was a vital function that maintained ecosystem functions in a river basin. Before large dams were built, floods were an annual event. The silt rich waters were allowed to flow through the village homes as the residents moved upstairs with their belongings. With recession of the floodwaters, (which normally took 5-6 hours owing to the steep gradient of the river) the first floors were cleaned (by using the remaining flow of floodwaters), and normal life resumed. House cleaning locally known as 'osojii' was conducted during moderate to strong flood events. In these times flood was referred to as 'kozui' meaning 'large water flow', and not as 'suigai' or water hazard -a term that increasingly came into use in the $20^{\text {th }}$ century. Large dams not only stop this vital function, they can lead to a worsening of the flooding scenario, effectively making floods 'hazards'. The strong opposition to the Kawabegawa dam and the support for removal of the Arase dam in the watershed were related to this realization in some part. In addition, after dams were built, constant removal of woody debris and leaf litters from the riverbed to the upstream of the dams became necessary as they are thought to impair the function of the dams (figure 8). Sediment transport and 


\section{MInstitute ${ }^{\text {Mink }}$}

Issues in Social Science

ISSN 2329-521X 2016, Vol. 5, No. 1

discharge mechanisms have changed significantly, and ironically, the nutrient that once replenished the river system is now seen as 'debris' or 'waste'. Researches indicate that woody debris or organic matters serve vital ecological functions of natural rivers as they help sustain biological diversity and are important for fish ecology during their decomposition and course downstream (Inoue \& Nakano, 1998; Wohl, 2005, Dolloff \& Warren 2003, Nicol et al. 2004; Beechie et al. 2005). The silt and organic matter supply of the river allowed the rich intertidal zone of the Yatsushiro bay to form. Moderate $(1.0 \mathrm{~m})$ to high $(3.0 \mathrm{~m}) \mathrm{spring}$ tide characterizes this zone (Masanori, 2004). In the recent years, effects of changes have increasingly appeared in the tidal flat (figure 9). The mudflat is about $200 \mathrm{~km}^{2}$ covering about $40 \%$ of the total area of tidal mudflats in Japan (Park et al. 2012).
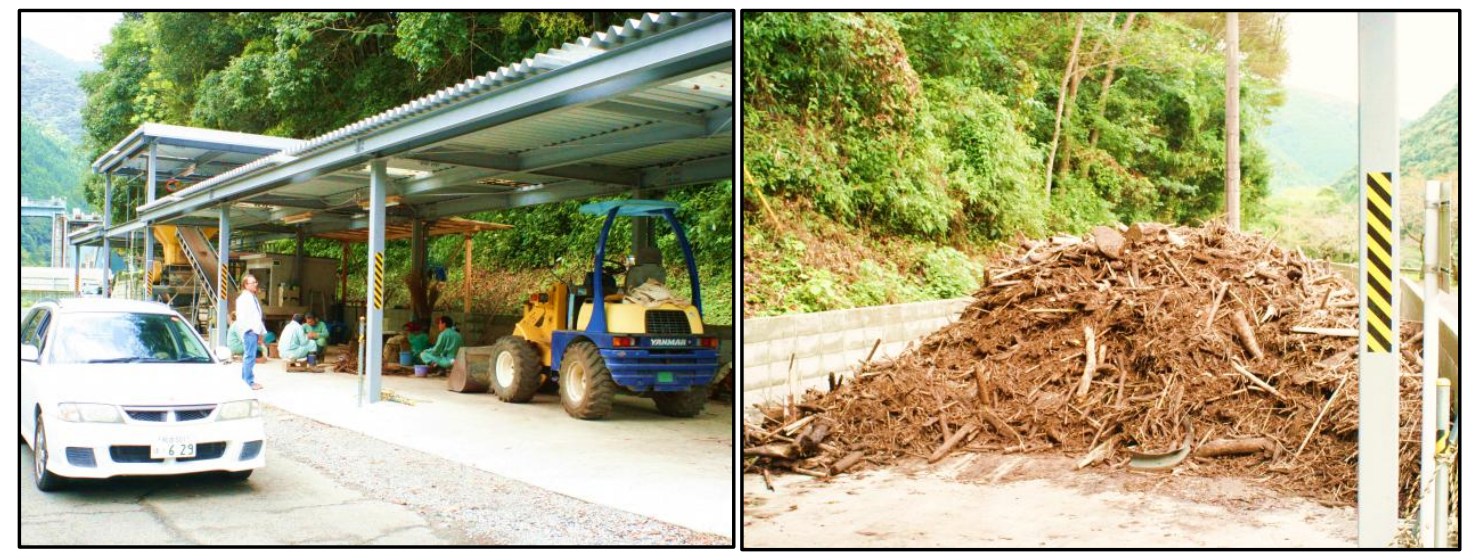

Figure 8 . Removal of woody debris from the river above Setoishi dam. (Photograph by the authors)

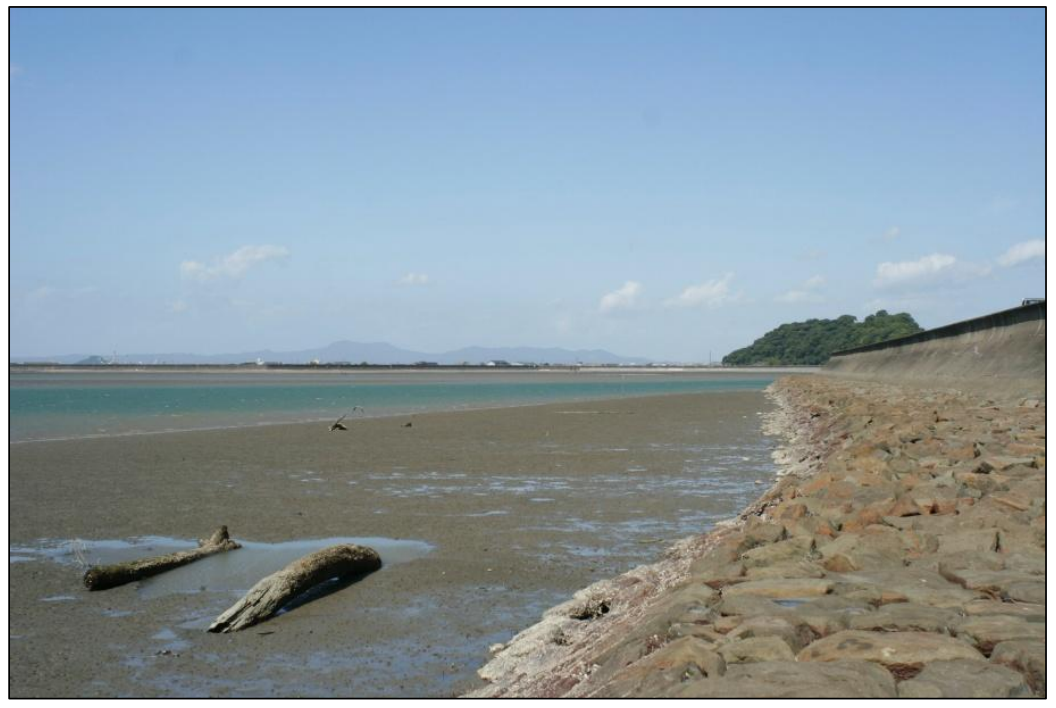

Figure 9. Kuma River flowing out to Ariake Sea; creating a vast mudflat. (Photograph by the authors) 


\section{$\Lambda$ Macrothink}

Local fishermen suggested that the sheltered and clear waters of the Yatsushiro Bay allowed a profusion of eelgrass (Zostera marina), along with Hijiki (Sargassum fusiform) and green laver (Enteromorpha and Ulva) which the local people harvested. Maeyama (1997) notes rich forests in the uplands of the Kuma watershed used to provide leaf litters and debris. Organic matter came from the mountain forests and managed coppice woodlands together with sediments. This connectivity ensured a nutrient rich environment in the Yatsushiro Bay; creating mudflats that support seagrass and algae ecosystem. This cycle has now broken down almost completely, with the dams and concretization of bed and banks. The aggradation function of the river is hampered, as organic and inorganic debris cannot flow to the ecosystem of the intertidal zone. Immediate effects are reflected in the damaged estuarine habitat. Decreased stream competency and capacity (Note 9) below the dams today result in only the finest grained materials, and materials from below the dam catchments reaching the bay. Decreasing silt and increasing mud have adversely affected photosynthesis process in the estuarine area, eventually resulting in decreased seagrass beds and degradation of the ecosystems that depend on it. The lotic (flowing water) ecosystem of the downstream reaches has been changed to a significant extent as a result. Tidal mudflats support specially adapted organisms to the anoxic conditions. Seagrasses and diatoms break the nutrients in the mudflats to make them available for other higher order organisms thereby sustaining ecosystems over wider areas. Mudflat ecosystems house fish, mollusks, octopuses, squids, and crustaceans, and also attract waders and other migratory birds thereby connecting and distributing nutrient flows, making them some of the highly valued ecosystems in the world (Costanza, 1997). The loss of seagrass and mudflat ecosystems means loss of resilience of coastal ecosystems and degradation of ES.

Due to the retardation of a large amount of water inside the dam reservoir, the downstream flow volume decreased, this exposes riffle areas permanently above the surface of the river water with perennial grass cover (figure 10). According to the fishermen who target sweetfish and freshwater eels, the pool and riffle sequence that is vital for ecosystem functions and for maintaining the natural channel diversity has changed after the dams and artificial levees were built; many important pool-riffle sequence have since disappeared totally. In natural or relatively undisturbed rivers, riffles house insects and mosses, on which the fish feed. Riffles are also used by the fish for laying eggs amongst the complex of rocks and aquatic vegetation. Pools provide deeper water and gentle flow, ideal for the fish to rest and hide from predators. The alteration of pool and riffle sequence in the river thus damages the natural streambed and its biodiversity. 


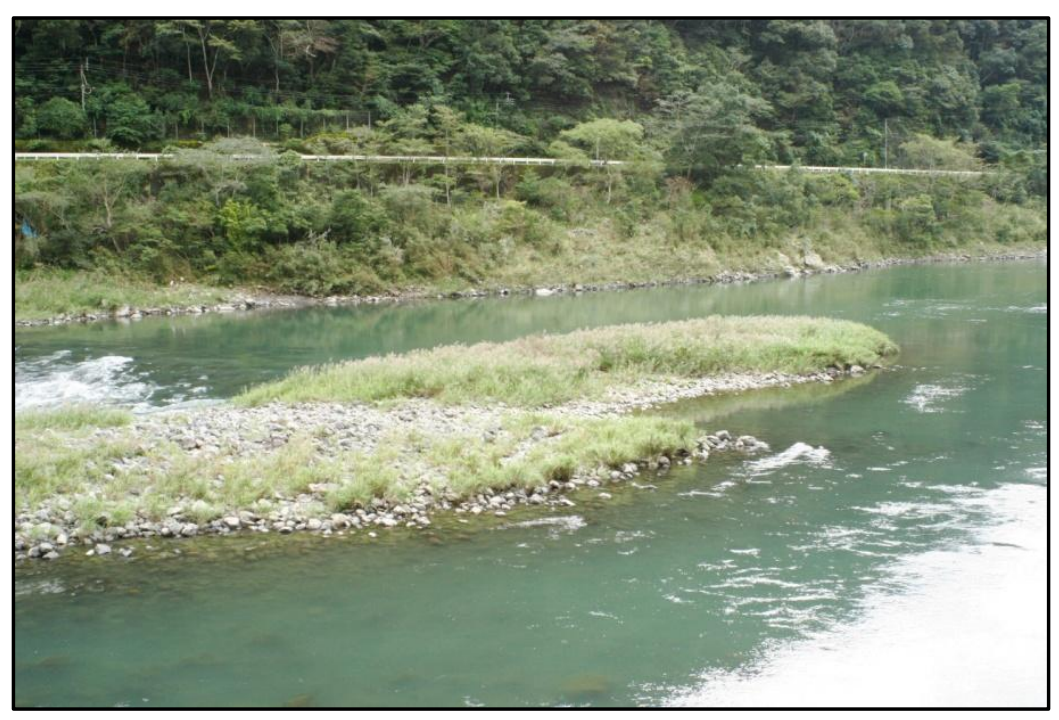

Figure 10. Deposition of sediment loads with perennial grass cover in riffle sequences below Arase dam (Photograph by the authors)

Fishing provides an important source of sustenance for local societies and the 'pulse' mechanisms of the basin, including flooding and coastal-freshwater interchange are important mechanisms for sustaining the fish population. This can be exemplified through the case of sweetfish or ayu - a fish often mentioned by the locals during the interviews. While the Kuma River is known for its rich sweetfish stock and attracts a large number of fishing enthusiasts during the sweetfish fishing season, the fish is no longer a 'natural' inhabitant across the watershed. Sweetfish typically move upriver to spawn, but the Yohai barrage currently restricts any significant upriver migration beyond it (figure 11). The sweetfish are therefore caught below the barrage and released upstream in truckloads to mimic the fish cycle from upriver (Kuma River Fisheries Cooperative, n. d.). This practice is supported because the sweetfish is related to the local economy; it fetches a large sum of money annually through business and sport fishing. The Amphidromous Rhinogobius (goby) was another well-mentioned species that were found in abundance in the river before the dams were built. Freshwater eels, which breed and spawn in the rocky riverside also suffered due to concretization of riverbanks and flow diversions. Weather loach (Misgurnus anguillicaudatus), and Chinese Soft-shell turtle (Pelodiscus sinensis) were mentioned frequently during the interviews as the species that were used as food by the local fishermen, but these species have decreased significantly. The Japanese rice fish (Oryzias latipes) another species mentioned to have decreased in the area is also listed as vulnerable species on the Japan Red Databook of threatened species, and Pelodiscus sinensis is a vulnerable species mentioned in IUCN Red List (MoE N.D; Asian Turtle Trade Working Group, 2016). Their decrease marks the deterioration of the zone of aggradation; as these species variously spawned and thrived in the lowland rivulets, rice paddies, ponds and swamp environments. 


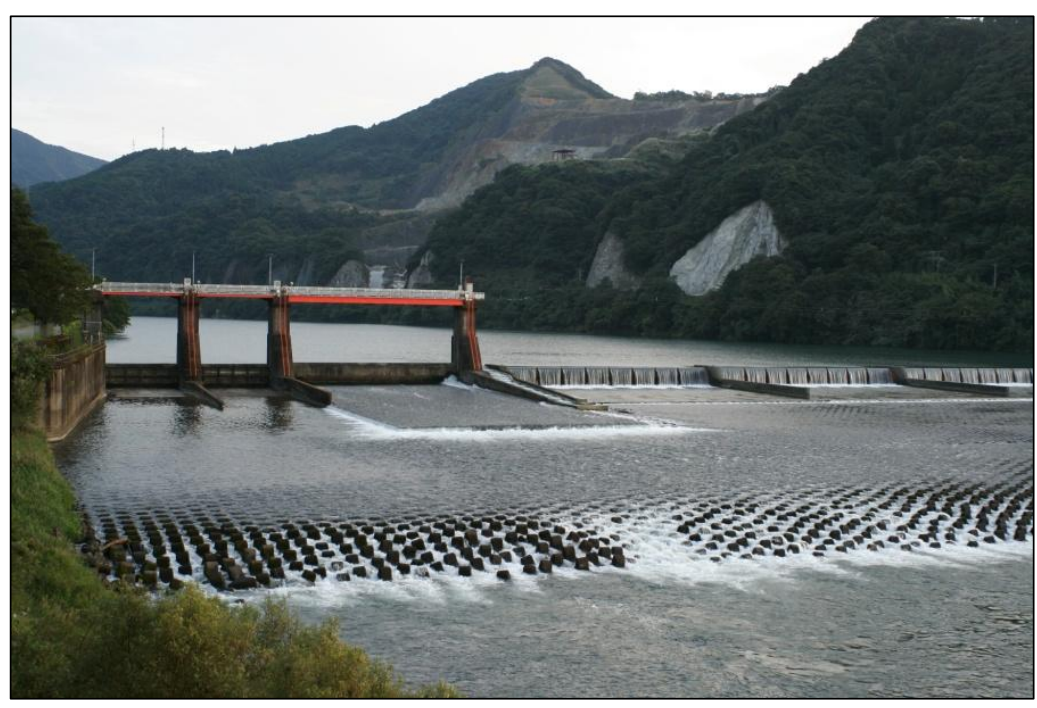

Figure 11. Yohai barrage, where sweetfish are captured and discharged artificially upriver (Photograph by the authors)

Although it appears that the local community is now sensitive to the human engineering of the river's natural mechanisms, most of the protests are directed against obvious structures such as dams. Even without dam construction, human intervention on the ecosystems has been extensive: high weirs, embankments and built surfaces have altered runoff properties of the river extensively, resulting in the swift decline of species such as the goby, loach and ricefish. While some economically important fish like the sweetfish has fared better, other species, which do not have similar economic value, have not enjoyed comparable success.

\section{Conclusion:}

In this article, we discussed how socio-ecological production landscapes like the satoyama are integrally linked with ecological connectivity. This connectivity does not merely mean the interrelationships between a few components managed by the human societies within a small 'patch' of landscape, it implies broader connectivity involving mountains, forests, rivers and coastal areas as an organic spread over multiple spatial scales. Human disturbance regimes can supplement a part of this landscape diversity if they are conducted in a situation whereby the ecological integrity of the larger scales (in this case the watershed level processes mark the main parameters) is maintained. Once key components are fragmented due to human intervention the net resulting loss is reduced ecological resilience and a reduction of the diversity of the landscape. From this case study we could get insight of how this fragmentation occurred in the Kuma River Basin: riverine functions were changed due to wet-rice cultivation and the ecological connectivity broke down when dams were built; leading to a further and more profound cascade of changes. These changes were also amplified by the loss of the original forest cover. The main lesson for sustainable development is, even as 'satoyama' type socio-ecological landscapes are partly managed by human actions, once the overarching mechanism starts to break down, the system cannot be managed solely from a human-centric approach; i.e. the human component in such socio-ecological landscapes cannot outgrow their ecosystem service pathways that are rooted 
in the natural system; and therefore any meaningful approach to sustainable management must involve restoration of these pathways. These pathways in turn could be identified through 'critical transition events' in the past that provide 'beacons' or indicators for system connectivity and large spatial dynamics. Critical transition events in this case include: degradation of beech forests and evergreen broadleaved forests, disappearance of slash and burn agriculture, reduction of coppicing as a forest management practice, and the dissociation of the basin society from floods. Through the erosion of these land-and-people connections, an erosion of ecosystem services in the socio-ecological landscape has taken place. This can only be understood when change is evaluated in terms of riverine functions as well as the characteristics of the surrounding landscapes. Changes in landscape connectivity can jeopardize the natural stocks and flows that are needed to sustain ecosystems as a whole. As this case shows the state and changes in the river basins can be a good indicator for the sustainability and change of socioecological landscapes. As satoyama is a type of agro-ecological landscape, and one that is integrally related with ecosystem services from rivers, understanding the landscapes in a river-basin context is a key for managing such socioecological landscapes in a sustainable manner. As Japan seeks to develop landscape management based on satoyama and satoumi (the marine version of satoyama) ecosystems, river systems need re-appraisals as vital landscape units that can be studied for linkages between different ecosystem components.

\section{Acknowledgement}

The authors would like to thank Ms. Shoko Tsuru of Kumagawa-Shiranuikai Basin Association for kind assistance during the fieldwork. The first author of the paper is grateful for the support of Japan Society for the Promotion of Science (JSPS) Kaken-hi research grant (Grant No. 15F15784).

\section{References}

Abbot, P. G., \& Lowore, J. D. (1999). Characteristics and management potential of some indigenous firewood species in Malawi. Forest Ecology and Management, 119(1-3), 111-121. http://dx.doi.org/10.1016/S0378-1127(98)00516-7

Asian Turtle Trade Working Group. (2000). Pelodiscus sinensis. The IUCN red list of threatened species 2000: e.T39620A97401140 [WWW page]. Accessed from http://www.iucnredlist.org/details/39620/0

Bahar, M., Ohmori, H., \& Yamamuro, M. (2008). Relationship between river water quality and land use in a small river basin running through the urbanizing area of central Japan. Limnology, 9, 19-26. http://dx.doi.org/10.1007/s10201-007-0227-z

Beechie, T.J., Liermann, M., Beamer E. M., \& Henderson R. (2005). A classification of habitat types in a large river and their use by juvenile salmonids. Transactions of the American Fisheries Society, 134(3), 717-729. http://dx.doi.org/10.1577/T04-062.1

Berkes, F. (2004). Rethinking community-based conservation. Conservation Biology, 18, 621-630. http://dx.doi.org/10.1111/j.1523-1739.2004.00077.x 


\section{Macrothink}

Brown, R.D., \& Yokohari, M. (2003). Ideological contribution of satoyamas. In K. Takeuchi, R. D Brown, I. Washitani, A. Tsunekawa, \& M. Yokohari (Eds.), Satoyama: The Traditional Rural Landscape of Japan (1-7). Tokyo: Springer.

Cetinkaya, G. (2009). Challenges for the maintenance of traditional knowledge in satoyama and satoumi ecosystems, Noto Peninsula, Japan. Human Ecology Review, 16 (1), 27-40. Accessed from http://www.humanecologyreview.org/pastissues/her161/cetinkaya.pdf

Chakraborty, A., \& Chakraborty, S. (2013). Satoyama: A landscape conservation discourse of romantic nostalgia and reflexive modernity in 'post growth' Japan. Japan Studies Association Journal, 11, 46-64.

Committee for Dam Removal. (2010). Datsu damu e no michinori: Koushite jumin wa kawabegawa damu wo tometa (Towards dam removal: This is how locals stopped the building or Kawabe River dam). Kumamoto: Kumamoto Shuppan Bunka Kaikan.

Creswell, J. W. (2002). Research design: Qualitative, quantitative and mixed method approaches. Thousand Oaks: Sage.

Dolloff, C. A., \& Warren, M. L. Jr. (2003). Fish relationships with large wood in small streams. American Fisheries Society Symposium, 37, 179-193. Accessed from https://www.srs.fs.usda.gov/pubs/ja/ja_dolloff002.pdf

Duraiappah, A. K., Nakamura, K., Takeuchi, K., Watanabe, M., \& Nishi, M. (2012). Satoyama-satoumi ecosystems and human well being: Socio-ecological production landscapes of Japan. Tokyo: United Nations University Press.

Fisher, B., Turner, R. K., \& Morling, P. (2009). Defining and classifying ecosystem services for decision making. Ecological Economics, 68(3), 643 - 653. http://dx.doi.org/10.1016 /j.ecolecon.2008.09.014

Fukamachi, K., Oku, H., \& Nakashizuka, T. (2001). The change of satoyama landscape and its causality in Kamiseya, Kyoto Prefecture, Japan. Landscape Ecology, 16, 703-717. http://dx.doi.org/10.1023/A:1014464909698

Gomez-Baggethum E., de Groot R., Lomas L. P., \& Montes, C. (2010). The history of ecosystem services in economic theory and practice: from early notions to markets and payment schemes. Ecological Economics, 69, 1209-1218. http://dx.doi.org/10.1016 /j.ecolecon.2009.11.007

Haslam, S. M. (2008). The riverscapes and the river. Cambridge: Cambridge University Press.

Hillel, D., \& Rosenzweig, C. (2008). Biodiversity and food production. In E. Chivian, \& A. Bernstein (Eds.), Sustaining life: How human health depends on biodiversity (325-381), New York: Oxford University Press. 
Honnay, O., Jacquemyn, H., Bossuyt, B., Hermy, M. (2005). Forest fragmentation effects on patch occupancy and population viability of herbaceous plant species. New Phytologist, 166, 723-736. DOI: 10.1111/j.1469-8137.2005.01352.x

Indrawan, M., Yabe, M., Nomura, H., \& Harrison, R. (2014). Deconstructing satoyama: The socioecological landscape in Japan. Ecological Engineering, 64, 77-84. DOI: 10.1016/j.ecoleng.2013.12.038

Inoue, M., \& Nakano, S. (1998). Effects of woody debris on the habitat of juvenile masu salmon (Oncorhynchus masou) in northern Japanese streams. Freshwater Biology, 40, 1-16. DOI: 10.1046/j.1365-2427.1998.00346.x

Inui, T. (2002). Satoyama to Hito no Rireki (Chronicle of Satoyama and Human Societies). Tokyo: Shinsishakusha.

Katoh, K., Sakai, S., \& Takahashi, T. (2009). Factors maintaining species diversity in satoyama, a traditional agricultural landscape of Japan. Biological Conservation, 142 (9), 1930-1936. http://dx.doi.org/10.1016/j.biocon.2009.02.030

Kennedy, A. D. (1998). Coppicing of tarconanthus camphoratus (compositae) as a source of sustainable fuelwood production: An example from the laikipia plateau, Kenya. African Journal of Ecology, 36 (2), 148-158. http://dx.doi.org/10.1046/j.1365-2028.1998.00115.x

Kobori, H. \& Primack, R. B. (2003). Participatory conservation approaches for satoyama, the traditional forest and agricultural landscape of Japan. AMBIO: A Journal of the Human Environment, 32 (4), 307-311. http://dx.doi.org/10.1579/0044-7447-32.4.307

Kohsaka, R., Shih, W., Saito, O, \& Sadohara, S. (2013). Local Assessment of Tokyo: Satoyama and satoumi-Traditional landscapes and management practices in a contemporary urban environment. In T. Elmqvist, M. Fragkias, J. Goodness, B. Guneralp, P. J. Marcotullio, R. I. McDonald, S. Parnell, M. Schewenius, M. Sendstad, K. C. Seto, \& C. Wikinson (Eds.), Urbanization, biodiversity and ecosystem services: Challenges and opportunities (93-105). New York: Springer.

Kubota, M. (2008). Kawa to ikiru-nagaragawa, ibigawa monogatari (Living with rivers: Tales from Nagara and Ibi Rivers). Nagoya: Fubaisha.

Kuma River Fisheries Cooperative. (n. d.). Ayu no chigyo-chukan ikusei-houryu (Ayu fingerlings, intermediate breeding, discharge). Accessed from http://www.kumagawa .or.jp/work.html

Kumagawa Ryuiki Jumin Kikitori Chosa Hokoku Henshu Iinkai (Committee for Reporting on Residents Opinion Survey at Kuma River Basin). (2008). Damu ha suigai wo hikiokosuKumagawa Kawabegawa no suigai higaisha ha kataru (Dams cause floods: Residents of Kuma and Kawabe River basins voice their opinion). Tokyo: Kadensha.

Kumamoto Nichinichi Shimbun, (n. d.). Photo library. Accessed from https://bp.kumanichi.com/photo/archives/list 


\section{MInstitute ${ }^{\text {Mink }}$}

Kumamoto Prefectural Website. (n. d.). Ichifusa damu no gaiyo (An outline of Ichifusa dam). Accessed from http://www.pref.kumamoto.jp/kiji_6964.html

Lindborg, R, \& Eriksson, O. (2004). Historical landscape connectivity affects present plant species diversity. Ecology, 85, 1840-1845. http://dx.doi.org/10.1890/04-0367

Maeyama, M. (1997). Kumagawa Monogatari (Tale of the Kuma River). Fukuoka: Ashishobo.

Masanori, S. (2004). Ariake kai no utakasa to sono kiki (Richness of Ariake Sea in Kyushu, Japan and its crisis by human impacts). Saga Nature Study 10, 129-149. Accessed from http://ambiente.la.coocan.jp/ss0242/03/03-08/satou.pdf

MEA (Millennium Ecosystem Assessment). (2005). Ecosystems and human well-being, synthesis. Washington: Island Press.

Miyawaki, A. (1984). A Vegetation ecological view of the Japanese archipelago. Bulletin of Institute of Environmental Science and Technology, Yokohama National University, 11, 85-101.

MLIT (Ministry of Land, Infrastructure, Transport and Tourism). (2013). Kuma gawa karyuiki no kankyo saisei no arikata ni tsuite (Regarding pathways for environmental restoration in lower Kuma River basin). Committee for Lower Kuma Watershed Design. Accessed from http://www.qsr.mlit.go.jp/yatusiro/site_files/file/river/utsukushi/kankyodesign /04_shiryo1.pdf

MLIT (Ministry of Land, Infrastructure, Transport and Tourism). (2006). Kumagawa suikei ryuiki oyobi kasen no youko (An overview of Kuma river and its watershed). Accessed from http://www.mlit.go.jp/river/shinngikai_blog/shaseishin/kasenbunkakai/shouiinkai/kihonhoush in/060810/pdf/ref6.pdf

MoE (Ministry of the Environment) (2001). Study on satochi-satoyama in Japan: Interim Report. (in Japanese). Accessed from http://www.env.go.jp/nature/satoyama/chukan.html

MoE (Ministry of the Environment). (n. d.). Red list of threatened species in Japan. Accessed from http://www.biodic.go.jp/english/rdb/red_fishes.txt

Mugishima, K. (1949 a). Mokutan hakobi (Carrying charcoal).Accessed from http://bp.kumanichi.com/photo/archives/list?cat=136\&page=34\&sort=new

Mugishima, K. (1949 b). Ikada nagashi (Floating roundtimber downstream). Accessed from https://bp.kumanichi.com/photo/archives/list?words=筏流し

Nagayama, S., Kawaguchi, Y., Nakano, D., \& Nakamura, F. (2009). Summer microhabitat partitioning by different size classes of masu salmon (Oncorhynchus masou) in habitats formed by large wood in a large lowland river. Canadian Journal of Fisheries and Aquatic Sciences, 66 (1), 42-51. 


\section{Macrothink}

Nicol, S. J., Lieschke, J. A., Lyon J. P, \& Koehn, J. D. (2004). Observations on the distribution and abundance of carp and native fish, and their responses to a habitat restoration trial in the Murray River, Australia. New Zealand Journal of Marine and Freshwater Research, 38, 541-551.

Ono, A. (2010). Yama, kawa umi no kankyo shakai gaku (Environmental sociology of mountains, rivers and seas). Kyoto: Bunrikaku.

Otero, I. Boada, M., \& Tabara, J. D. (2013). Social-ecological heritage and the conservation of Mediterranean landscapes: A case study in Olzinelles (Catalonia). Land Use Policy, 30, 25-37.

Park, J., Khim, J.S., Ohtsuka, T., Araki, H., Witkowski, A., \& Koh, C. (2012). Diatom assamblages in Nanaura mudflat, Ariake sea, Japan: With reference to biogeography of marine benthic diatoms in Northeast Asia. Botanical Studies, 53, 105-124. Accessed from https://ejournal.sinica.edu.tw/bbas/content/2012/1/Bot531-11.pdf

Sano, H., Honjo, T. and Ida, T. (2006). New folky mountain system for establishing energy independence. Journal of the Japan Institute of Energy, 85, 42-48. Accessed from https://www.jstage.jst.go.jp/article/jie1992/85/1/85_1_42/_pdf

Save the River Kawabegawa. (2007). Kuma gawa ryuiki ni okeru shinrin hensen to sore ga motarasu kousui ryushutsu he no eikyou. (Forest change in the Kuma River Basin and its relationship to flooding) Accessed from http://kawabegawa.jp/moushiire /06.6.6shinrinhenka.pdf

Seidl, R., Spies, T. A., Peterson, D. L., Stephens, S. L., \& Hicke, J. A. (2015). Searching for resilience: addressing the impacts of changing disturbance regimes on forest ecosystem services. Journal of Applied Ecology, 53 (1), 120-129. http://dx.doi.org/10.1111/1365 $-2664.12511$

Senelwa, K., \& Sims, R. E. H. (1999). Fuel characteristics of short rotation forest biomass. Biomass and Bioenergy, 17 (2), 127-140. http://dx.doi.org/10.1016/S0961-9534(99)00035-5

Shiiba, Y., \& Utsumi, Y. (2010). Miyazaki ken shiba mura okawachi chiku ni okeru yakihata nogyo. (Slash and burn agricultural practices in Okawachi area, Shiiba village in Miyazaki Prefecture). Bulletin of Kyushu University Forestry Department, 91, 34-39.

Swift, M. J., Izac, A. M. N., \& van Noordwijk, M. (2004). Biodiversity and ecosystem services in agricultural landscapes - are we asking the right questions? Agriculture, Ecosystems and Environment, 104, 113-134. http://dx.doi.org/10.1016/j.agee.2004.01.013

Tabata, H. (2001). The future role of satoyama woodlands in Japanese society. In Y. Yasuda (Ed.), Forest and Civilisation. New Delhi: Roli Books Pvt. Ltd. Accessed from http://www001.upp.so-net.ne.jp/ito-hi/satoyama/docs/

Takahashi, Y. (2009). Kawabegawa damu wa iranai (Kawabegawa dam is not needed). Tokyo: Iwanami Shoten. 


\section{Macrothink}

Takeuchi, K., Brown, R. D., Washitani, I., Tsunekawa, A., \& Yokohari, M. (Eds.). (2003). Satoyama: The traditional rural landscape of Japan. New York: Springer.

Tanabe, N. (2014). Arase dam: Japan's first dam removal project underway. JFS Newsletter No. 147. Accessed from http://www.japanfs.org/en/news/archives/news_id035105.html

Tanaka H., Seta, M. \& Saito, S. (2005). Rekishiteki na kawa secchi no hozen katsuyou ni tsuite (Conservation and restoration of historical river facilities). Riverfront Research Note, 16. 206-213. Accessed from http://www.rfc.or.jp/rp/files/16-27.pdf

Ushijima, M. (1984). Kumamoto no kawa to seikatsu (Rivers and lives of Kumamoto). Kumamoto: Kumanichi shuppan.

Ward, J. V. (1997). An expansive perspective of riverine landscapes: pattern and process across scales. Gaia, 6, 52-60. http://dx.doi.org/10.14512/gaia.6.1.6

Ward, J. V., \& Stanford, J. A. (1995). The serial discontinuity concept: Extending the model to floodplain rivers. River Research Applications, 10(2-4), 159-168. http://dx.doi.org/10.1002/rrr.3450100211

Watanabe, T., Okuyama, M., Fukamachi, K. (2012). A review of Japan's environmental policies for satoyama and satoumi landscape restoration. Global Environmental Research, 16, 125-135.

Wilby, A., Mitchell, C. E., Blumenthal, D., Daszak, P., Friedman, C., Jutro, P., Mazumder, A., Prieur-Richard, A. H., Desprez-Loustau, M. L., Sharma, M., \& Thomas, M. B. (2009). Biodiversity, food provision and human health. In O. E. Sala, L. A. Meyerson, \& C. Parmesan (Eds.), Biodiversity change and human health: From ecosystem services to spread of disease, (13-40), Washington D. C.: Island Press.

Wild Bird Society of Japan, (n. d.). Kumagawa estuary. Accessed from http://www.wbsj.org /nature/hogo/others/iba/eng/146.html

Wohl, E. (2005). Compromised rivers: Understanding historical human impacts on rivers in the context of restoration. Ecology and Society, 10(2), 2, Accessed from http://www.ecologyandsociety.org/vol10/iss2/art2/

Yamamoto, S. (1957). Tea cultivation in the mountainous areas of Kyushu: Case study of Itsuki village in Kumamoto. Chirigaku hyoron, 30 (4), 275-289. Accessed from https://www.jstage.jst.go.jp/article/grj1925/30/4/30_4_275/_article/references/-char/ja/

Yamauchi, R. (1982). Kumagawa to noringyo (Kuma river and its agriculture and forestry). Kumagawa ga Hitoyoshi chiiki keizai ni oyobosu eikyou ni tsuite chousa houkokusho (Report on the influence of Kuma River on the economy of Hitoyoshi area), Kumamoto University of Commerce (Note 10).

Yokohari, M. Brown, R. D., Katoh, Y., \& Yamamoto, S. (2001). The cooling effects of the paddyfields on summertime air temperature in residential Tokyo, Japan. Landscape and Urban Planning, 53, 17-27. http://dx.doi.org/10.1016/S0169-2046(00)00123-7 


\section{Al Macrothink}

Issues in Social Science

ISSN 2329-521X

2016, Vol. 5, No. 1

Yokohari, M., \& Bolthouse, J. (2011). Keep it alive, don't freeze it: a conceptual perspective on the conservation of continuously evolving satoyama landscapes. Landscape and Ecological Engineering, 7 (2), 207-216. http://dx.doi.org/10.1007/s11355-010-0116-1

Yoshimura, C., Omura, T., Furumai, H., \& Tockner, K. (2005). Present state of rivers and streams in Japan. River Research and Applications, 21(2-3): 93-112. http://dx.doi.org /10.1002/rra.835

\section{Notes}

Note 1. Some of the notable endangered fish varieties found in the Kuma basin are: Lethenteron reissneri (suna yatsume), Acheilognathus cyanostigma (ichimonji tanago), Hippichthys penicillus (ganteninshiyouji), Apocryptodon punctatus (tabirakuchi), Boleophthalmus pectinirostris (mutsugoro), Leucopsarion petersii (shirouo), Luciogobius pallidus (idomimizuhaze), Gymnogobius scrobiculatus (kubohaze)

Note 2. These forests were characterized by stands of Nagi (Nageia nagi), Ichiigashi (Quercus gilva), Tabu (Machilus thunbergi), Tsuga or Japanese Hemlock (Tsuga sieboldii), Edohigan (Cerasus spachiana Lavalee), Kagonoki (Litsea lancifolia), Momi (Abies firma), Mukunoki (Aphananthe aspera), Nigaki (Picrasma quassioides). Originally, evergreen broadleaved forests formed main forest

Note 3. Azhuchi Momoyama period spanned from 1573-1603 AD

Note 4. Edo Period Spanned from 1603-1868 AD

Note 5. Daimyo means administrative official of the feudal government

Note 6. During this time coppice woodlands also began to decline all over Japan in general as woodfuel and charcoal utilization decreased due to increasing use of propane gas from the 1960s (Tabata, 2001).

Note 7. Their observation is derived from the works of Abbot and Lowore (1999), Kennedy (1998), Senelwa and Sims (1999).

Note 8 . In this paper by 'pre-modern time' we refer to a time period from about 1600 AD to 1868 AD (the time of Meiji Restoration).

Note 9. Stream competency refers to the maximum size of particle load that a stream can carry. Stream capacity is the total quantity of load that a stream can move.

Note 10. Kumamoto University of Commerce has been renamed as Kumamoto Gakuen University in 1994. 